\title{
Bacteriological Quality of Tilapia Fish from Treated Wastewater in Peri-Urban Areas, Morogoro, Tanzania
}

\author{
Ofred Jonas Mhongole ${ }^{1, ~ *}$, Robinson Hammerthon Mdegela ${ }^{1}$, Lughano Jeromey Moses Kusiluka ${ }^{1,2}$, \\ Anders Dalsgaard ${ }^{3}$
}

${ }^{1}$ Department of Veterinary Medicine and Public Health, Sokoine University of Agriculture, Chuo Kikuu, Morogoro, Tanzania

${ }^{2}$ Office of the Vice Chancellor, Mzumbe University, Morogoro, Tanzania

${ }^{3}$ Department of Veterinary Disease Biology, Copenhagen University, Frederiksberg C, Denmark

Email address:

ofredjonas@gmail.com (O. J. Mhongole), ojmmhongole@yahoo.co.uk (O. J. Mhongole)

${ }^{*}$ Corresponding author

\section{To cite this article:}

Ofred Jonas Mhongole, Robinson Hammerthon Mdegela, Lughano Jeromey Moses Kusiluka, Anders Dalsgaard. Bacteriological Quality of Tilapia Fish from Treated Wastewater in Peri-Urban Areas, Morogoro, Tanzania. Agriculture, Forestry and Fisheries.

Vol. 5, No. 5, 2016, pp. 202-206. doi: 10.11648/j.aff.20160505.19

Received: August 16, 2016; Accepted: September 5, 2016; Published: October 6, 2016

\begin{abstract}
The aim of this study was to assess faecal bacterial contamination in tilapia fish from wastewater treatment ponds at Mzumbe and in pristine water in Mindu dam. Tilapia fish (fish flesh and fish intestines) and water samples were analysed for Escherichia coli and total plate count. The concentration of $E$. coli in fish intestines ranged from about $1-3.5 \log \mathrm{cfu} / \mathrm{g}$ and $<1$ $\log \mathrm{cfu} / \mathrm{g}$ in fish flesh. Total plate count ranged from $1-3 \log \mathrm{cfu} / \mathrm{g}$ in fish flesh and $2-6 \log \mathrm{cfu} / \mathrm{g}$ in fish intestines. The concentration of $E$. coli in pristine water in Mindu dam ranged from 0 to $15 \mathrm{cfu} / \mathrm{mL}$. From the inlet to outlet of Mzumbe wastewater treatment pond, there was a significant reduction $(\mathrm{p}<0.05)$ of $E$. coli concentration along the gradient from 2.05 to $0.55 \log \mathrm{cfu} / \mathrm{mL}$, respectively. These findings demonstrated that tilapia fish from the two study sites were of good quality for human consumption based on microbial faecal contamination. On the other hand treated wastewater of the quality found in this study may be used for aquaculture. However, continuous monitoring for bacteriological quality and safety parameters including $E$. coli and total plate count is required.
\end{abstract}

Keywords: Escherichia coli, Fish Culture, Fish Flesh, Fish Intestines, Water

\section{Introduction}

The tilapia fish such as Oreochromis niloticus, is one of tropical species that inhabits in shallow water within temperature range of $11^{\circ} \mathrm{C}$ to $42^{\circ} \mathrm{C}$ [1]. Tilapia fish feeds on phytoplankton, periphyton, aquatic plants, small invertebrates, benthic fauna, detritus and bacterial films associated with detritus $[1,2]$. Worldwide, wastewater has been used in aquaculture farming though in most of SubSahara African countries including Tanzania, there are no policies and data to support wastewater fed aquaculture [35]. The driving forces to grow fish in wastewater and utilize them include the economical, scarcity of clean water and limited land for fish culture. Others include urbanization and population increase; and low cost or free available wastewater resource $[6,7]$. In tropical countries both forms of economic and physical water scarcity predominates depending on hydrologic conditions [8]. Not only that, but also, predominantly, stable surface water supply is during wet season and decreases during dry season [9]. Use of treated wastewater allows a constant supply of water in year round. The management of wastewater is important for sustainable development of aquatic resources in the world [10]. Wastewater or other low quality water sources - fed fish culture is among the productive sectors that enhances better nutrition and improves household food security and income generation [1]. It has been estimated by FAO that about 1 billion people rely on fish as source of protein [7]. Moreover, fish are rich source of omega 3 polyunsaturated fatty acids as well as minerals and vitamins [11].

Wastewater fed fish-culture may contain excreta related bacterial hazards which may lead to diseases such as 
gastroenteritis and Typhoid fever caused by pathogens like $E$. coli and Salmonella typhi, respectively. The E. coli and Salmonella have been reported to survive and multiply in the gut of fish cultured in wastewater fed ponds [12]. Fish grown in wastewater fed ponds are likely to be contaminated with pathogens since they feed on phytoplankton web-based and filters water contaminated with human and animal waste materials. It is also important to note that even fish that grows in a wild environment may directly feed on human or animal excreta [13], which may increase bacterial load in the gut. The occurrence of pathogenic bacteria in the gut of fish meant for human consumption may pose potential health risks to the handlers and consumers [14]. In Tanzania there is no food safety policy to support wastewater fed fish culture while fish grown in wastewater treatment ponds are consumed. Moreover, data on pathogenic bacterial contamination in fish grown in wastewater treatment ponds are required in order to ascertain the associated human health risks [15]. Customarily, pathogenic bacterial contamination has been monitored by assessing indicator bacteria such as total coliforms, E. coli and thermotolerant / faecal coliforms [16]. Escherichia coli is typically found in the intestines of warm-blooded animals including human and animals. It is thus a good indicator for monitoring faecal pathogenic bacterial contamination in water and foodstuffs including fish [17]. The hypothesis tested in this study was that fish from treated wastewater are of the same bacterial quality with those from pristine water. This study therefore assessed the occurrence of $E$. coli in tilapia fish grown in Mzumbe wastewater treatment ponds and Mindu dam which supplies water for residents in Morogoro urban and peri- urban areas.

\section{Materials and Methods}

This study was carried out during October, 2013 to February 2015 at Mzumbe wastewater treatment ponds and Mindu dam that serves as a source of fish from pristine environment. Mzumbe wastewater treatment ponds consist of anaerobic pond, facultative pond and maturation pond arranged in series. Man-made Mindu dam, pristine (clean) water reservoir is the main source of water for residents in Morogoro Urban and Peri-urban areas. It receives water from Mzinga, Ngerengere, Mlali, Lukulunge and Mgera rivers that flow from Uluguru Mountains into the dam and drains out through Ngerengere river. The dam is located about $10 \mathrm{~km}$ south west of Morogoro Municipality along Tanzania Zambia Highway towards Iringa Region. A total of 102 samples including 41 water and 61 tilapia fish were collected. Out of 41 water samples, 21 were from Mindu and 20 from Mzumbe wastewater treatment ponds. Out of 61 Tilapia fish samples, 41were from Mzumbe wastewater maturation pond and 20 from Mindu dam. Samples were individually put in a polythene bags, then stored in a cool box with ice cubes. Immediately transported to Pest Management Centre laboratory, Sokoine University of Agriculture and analyzed in the same day.

\subsection{Microbiological Analysis}

To obtain fish flesh and intestines for laboratory analysis, in brief, the whole fish was placed on the sterile chopping board, then wiped using moistened cotton wool with $70 \%$ alcohol to decontaminate bacterial load on fish skin. Using hot knife, fish flesh was removed and placed on the chopping board with fish flesh placed upside. Aseptically, by using a sterile blade, fish flesh was chopped in small pieces. About $15 \mathrm{~g}$ was weighed into $120 \mathrm{~mL}$ of diluent (buffered peptone water-BPW, Oxoid Ltd, England) in $500 \mathrm{~mL}$ bottle and thoroughly mixed by hand. Fish intestines were removed using sterile forceps and then weighed to about $10 \mathrm{~g}$ into 90 $\mathrm{mL}$ of BPW in $250 \mathrm{~mL}$ bottle and thoroughly mixed by hand. Serial dilutions were prepared up to 10:10000 as per sample requirement. For enumeration of E. coli: one (1) $\mathrm{mL}$ of selected sample homogenate (fish flesh, fish intestines and water) was inoculated on petrifilm selective E. coli (SEC) plates (3M Microbiology Products, St Paul, USA) and incubated at $44^{\circ} \mathrm{C}$ for 24 hours. For total plate count: one (1) $\mathrm{mL}$ from the sample homogenate was inoculated into petri dish and pour plated with a molted Nutrient agar (NA), (Oxoid limited, Hampshire, England) and incubated at $37^{\circ} \mathrm{C}$ for 24 hours. All colonies from SEC plates and NA were counted and reported as E. coli/TPC in cfu/g or cfu per mL for fish and water samples, respectively.

\subsection{Data Analysis}

Data were entered in Microsoft excel and further analyzed using SPSS statistics 20.0 of 2011 (IBM, California, USA). The concentration of $E$. coli and total plate count was reported in colony forming units (cfu) per $\mathrm{mL}$ and transformed to $\log _{10}$ cfu per $\mathrm{mL}(\log \mathrm{cfu} / \mathrm{mL})$. Paired sample means of $E$. coli concentration in $\log \mathrm{cfu} / \mathrm{mL}$ between Mzumbe and Mindu were tested by Student's t-test. Concentration of E. coli and total plate counts for paired sample means was compared between the two study sites to ascertain if there were differences. The differences between groups were reported at $\mathrm{P}<0.05$. The mean concentration of E. coli and TPC were presented in Boxplots.

\section{Results and Discussion}

\subsection{Escherichia Coli Concentration in Fish Flesh and Intestines}

These findings give the basis for the bacteriological quality of fish grown in domestic wastewater treatment ponds. Although fish flesh is sterile [18], it may become contaminated with faecal pathogenic bacteria, if it is grown in polluted environment [7, 19]. These findings demonstrated the risk of faecal bacterial contamination in tilapia fish in the two study sites. Occurrence of E. coli in fish flesh from Mzumbe wastewater treatment ponds and Mindu dam was $0.05 \%$ $(\mathrm{n}=41)$ and $0 \%(\mathrm{n}=20)$, while in fish intestines was $68 \%$ $(\mathrm{n}=41)$ and $40 \%(\mathrm{n}=20)$, respectively. The concentration of $E$. coli in fish flesh in the two study sites was $<1 \log \mathrm{cfu} / \mathrm{g}$ 
(detection limit) (Fig. 1) and in fish intestines was about 2 log $\mathrm{cfu} / \mathrm{g}$ and $3 \log \mathrm{cfu} / \mathrm{g}$ for fish from Mindu dam and Mzumbe water, respectively (Fig. 2). Concentration of E. coli in fish intestines was significantly higher $(\mathrm{P}<0.001)$ in Mzumbe wastewater than pristine water at Mindu dam. A comparable study in Brazil [20] found zero counts total and faecal coliforms equivalent to $<1 \log \mathrm{cfu} / \mathrm{g}$ in fish flesh and $3.0 \& 2.8$ $\log \mathrm{cfu} / \mathrm{g}$ in fish intestines, respectively. Likewise in Vietnam [21] pathogenic bacteria were found in fish intestines and in intraperitonial fluid without being found in fish flesh. However, the risk of pathogens invasion into fish flesh may increase with the duration of exposure to the polluted water. The contamination of $E$. coli in fish intestines was previously documented in comparable studies in Israel, Scotland, Norway, The Netherlands as well as in Tanzania [12, 22-25]. It was further found in Israel, Vietnam and Bangladesh that fish were contaminated with pathogens of faecal origin during culturing period, postharvest handling and processing $[19,26]$. A study in The Netherlands, reported contamination in different fish organs in the order of the intestine $>$ gills $>$ skin $>$ liver [23]. Microflora of fish intestines often reflects to the bacterial quality of aquatic environment [27, 28]. Thus, it implies that wastewater fed aquaculture may pose health risks to human and the aquatic organisms.

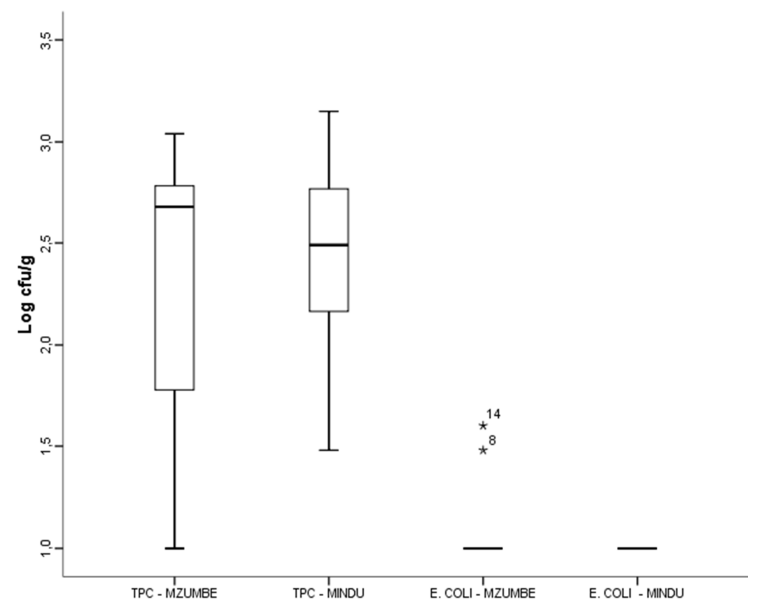

Figure 1. Microbial concentration in Fish flesh at the two study sites $\left(^{*}=\right.$ outlier samples).

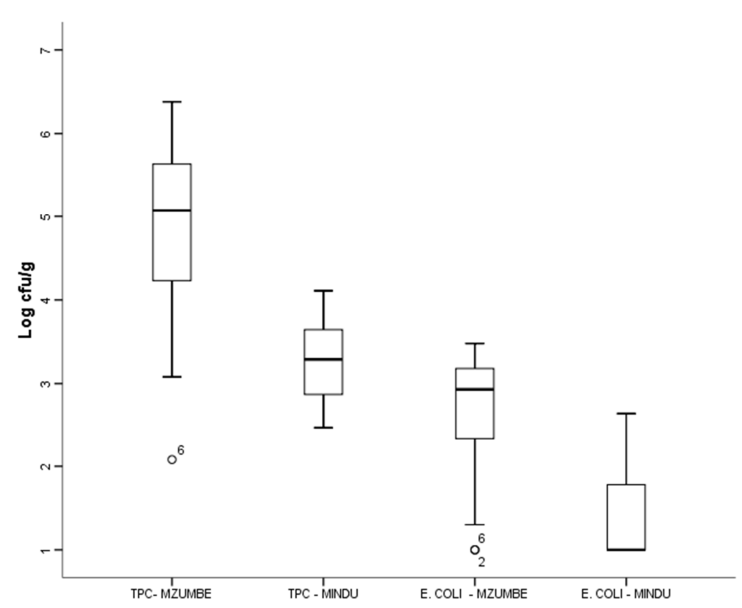

Figure 2. Microbial concentration in fish intestines $(O=$ outlier samples).

\subsection{Total Plate Count in Fish Flesh and Intestines}

Total plate count (TPC) in fish flesh (Fig. 1) from the two study sites were comparable $(\mathrm{P}>0.05)$. The mean density of TPC in fish flesh was $<3 \log \mathrm{cfu} / \mathrm{g}$. Studies on cultured freshwater fish in Kerala, India and Lagos, Nigeria found microbial counts ranging from 1-2 log cfu/g [29] and $4 \log$ cfu/g [30], respectively. Findings from this study indicate that concentration of TPC was below the ICMSF criteria of $5.60-7.00 \mathrm{log} \mathrm{cfu} / \mathrm{g}$. The TPC of $<5 \mathrm{log} \mathrm{cfu} / \mathrm{g}$ in fish flesh was reported earlier to indicate good quality of fish freshness [26]. Based on the density of TPC $(<3 \log \mathrm{cfu} / \mathrm{g})$ in fish flesh, it implies that fish from the two study sites were of good quality. The TPC in fish intestines from Mzumbe and Mindu dam was $>4 \mathrm{log} \mathrm{cfu} / \mathrm{g}$ and $<4 \mathrm{log}$ cfu/g, respectively (Fig. 2). Total plate count in fish intestines from Mzumbe was significantly higher $(\mathrm{P}<0.001)$ than those from Mindu dam. The concentration of $E$. coli in intermediate and treated wastewater in Mzumbe was higher (2.05 to $0.55 \mathrm{cfu} / \mathrm{mL}$ ) compared to about $1 \log \mathrm{cfu} / \mathrm{mL}$ in Mindu dam water. This implies that fish from Mzumbe are feeding on contaminated benthic fauna and aquatic plants [2]. The TPC in fish intestines ranged from 2-6 log cfu/g which was a low count compared to previous findings reported elsewhere [27, 30-32]. The TPC found were in the range of 7-8 $\log \mathrm{cfu} / \mathrm{g}$ implying that fish were not of good quality for processing or human consumption.

\subsection{Escherichia Coli in Water}

The occurrence of $E$. coli in intermediate treated wastewater entering into maturation pond and in treated wastewater at outlet was $80 \%(\mathrm{n}=10)$ and $70 \%(\mathrm{n}=10)$, respectively. There was significant reduction of $E$. coli concentration between two points of inlet and outlet of the maturation pond being 2.05 to $0.55 \log \mathrm{cfu} / \mathrm{mL}$, respectively. The occurrence of $E$. coli was $66 \%(\mathrm{n}=9)$ for samples from onshore and river catchments, $33 \%(n=3)$ off shore and $22 \%(n=9)$ inside the dam. The concentration of $E$. coli in both wastewater and pristine water in the present study were about $1 \log \mathrm{cfu} / \mathrm{mL}$ and it was in congruence with findings from a previous study in Brazil [20]. The concentration of $E$. coli was $1 \log \mathrm{cfu} / \mathrm{mL}$ in treated effluent from wastewater fed fish culture. The TPC is recognized as an acceptable measure for the general degree of bacterial quality and hygiene $[19,22]$. The $E$. coli from onshore water was $15 \mathrm{cfu} / \mathrm{mL}$ followed by Mzinga and Tangeni rivers catchments, off-shore water (about $200 \mathrm{~m}$ ) and inside the dam was 1-3 cfu/mL. These results were comparable with a study in Saudi Arabia [27], which documented TPC in the range of 0.45 to $1.20 \mathrm{log}$ units. Therefore, during the period of this study, water from the two study sites conformed to the WHO guidelines 2006.

\subsection{Food safety and Health Risks}

The presence of bacterial pathogens in fish intestines may lead to a food safety and health risks through cross contamination in fish flesh and transmission to consumers if 
good hygiene practices during fish preparation are inadequate [19]. Since $E$. coli is generic to intestinal tract of fish, it may lead to cross contamination on fish flesh during preparation if gut contents are exposed and ruptured. The risk for bacterial contamination in wastewater fed fishculture may be reduced based on the previous documented control measures that include: use of good quality treated wastewater; withholding and depuration of fish prior harvesting; good hygienic postharvest handling practices during processing and preparation; obligatory observation of personnel hygiene and use of protective gears; provision of clean water to fishers, processors, during kitchen preparation, satisfactory cooking of fish and fish products, and monitoring bacterial quality and safety indicator parameters in water and fish $[12,19,23,33]$.

\section{Conclusion}

Findings from the present study show that tilapia fish grown in wastewater treatment (maturation) pond conform to the bacteriological quality set by ICMSF/FAO. Overall, they were of good quality as those grown in the dam. The bacteriological quality of treated wastewater from the study sites conformed to the WHO guidelines (2006), thus it may be used for fish culture. Fish from wastewater treatment ponds in the study sites are consumed by the neighborhood community. So, health risks to handlers and consumers as well as other stakeholders can be reduced given that good hygiene handling practices during pre- and post- harvest of fish are adequately implemented. In Tanzania, neither a policy nor data are in place for wastewater fed fish-culture practices. These findings therefore may contribute data to the national and international bodies such as WHO/FAO on wastewater use in aquaculture. Further research for identification and characterization of faecal pathogenic bacteria including the pathotypes E. coli and Salmonella spp. in fish and water as well as health risk analysis is recommended.

\section{Acknowledgement}

We are grateful to the Danish International Development Assistance (DANIDA) funded project entitled "Safe Water for Food" (SaWaFo) for the financial support. Also we acknowledge the Management of Mzumbe University for accepting us to carry out this study at their wastewater treatment ponds. Finally we acknowledge the Management and staff of Pest Management Centre laboratory at Sokoine University of Agriculture for allowing us to use its laboratory for the analyses.

\section{References}

[1] FAO 2005. Cultured Aquatic Species Information Programme Oreochromis niloticus. Text by Rakocy, J. E. In: FAO Fisheries and Aquaculture Department [online], Rome.
[2] Kour, R. Bhatia, S. Sharma, K. K. 2014. Nile Tilapia (Oreochromis niloticus) as a successful biological invader in Jammu (J \& K) and its impacts on native ecosystem, Int. J. Interdiscip. Multidiscip. Stud. 1: 1-5.

[3] Bunting, S. W. 2004. Wastewater aquaculture: perpetuating vulnerability or opportunity to enhance poor livelihoods?, Aquat. Resour. Cult. Dev. 1:51-75.

[4] Mizyed, N. R. 2012. Challenges to treated wastewater reuse in arid and semi-arid areas, Environ. Sci. Policy. 25: 186-195.

[5] Sato, T. Qadir, M. Yamamoto, S. Endo, T. Zahoor, A. 2013. Global, Regional, and Country level need for data on wastewater generation, treatment, and use, Agric. Water Manag. 130: 1-13.

[6] Mateo-Sagasta, J. Medlicott, K. Qadir, M. Raschid-Sally, L. Drechsel, P. Liebe, J. 2013. Proceedings of the UN-Water project on the Safe Use of Wastewater in Agriculture, In: R. Liebe, J., Ardakanian (Ed.), UN-Water Decad. Program. Capacit. Dev. (UNW-DPC). Proceedings Ser. No. 11., UNWDPC, Bonn, Germany. pp. 1-79.

[7] WHO. 2006. WHO Guidelines for the Safe Use of Wastewater, Excreta and Greywater: Volume III - Wastewater and Excreta Use in Aquaculture, Geneva, Swilzerland.

[8] Valipour, M. 2013. Use of surface water supply index to assessing of water resources management in Colorado and Oregon, US, Adv. Agric. Sci. Eng. Res. 3: 631-640.

[9] Valipour, M. 2012. Hydro-Module Determination for Vanaei Village in Eslam Abad Gharb, Iran, ARPN J. Agric. Biol. Sci. 7: 968-976.

[10] Valipour, M. 2013. Evolution of irrigation-equipped areas as share of cultivated areas, Irrig. Drain. Syst. Eng. 02: 1-2.

[11] Hossain, M.A. 2011. Fish as Source of n-3 Polyunsaturated Fatty Acids ( PUFAs ), Which One is Better-Farmed or Wild?, Adv. J. Food Sci. Technol. 3 (6): 455-466.

[12] Buras, N. Duek, L. Niv, S. Hepher, B. Sandbank, E. 1987. Microbiological aspects of fish grown in treated wastewater, Water Res. 21: 1-10.

[13] Budiati, T. Rusul, G. Wan-abdullah, W.N. Ahmad, R. Arip, Y. M. 2015. Microbiological Quality of Catfish (Clarias Gariepinus) and Tilapia (Tilapia Mossambica) Obtained from Wet Markets and Ponds in Malaysia, J Aquac Res Dev. 6: $1-5$.

[14] Ampofo, J. A. Clerk, G. C. 2010. Diversity of Bacteria Contaminants in Tissues of Fish Cultured in Organic WasteFertilized Ponds: Health Implications, Open Fish Sci. J. 3: 142-146.

[15] Njoku, O. E. Agwa, O. K. Ibiene, A. A. 2015. An investigation of the microbiological and physicochemical profile of some fish pond water within the Niger Delta region of Nigeria, African J. Food Sci. 9: 155-162.

[16] URT. 2007. The Environmental Management (Water Quality Standards) Regulations. The Environmental Management Act (CAP.191). United Republic of Tanzania.

[17] Fox, B. Tamaru, C. Hollyer, J. Castro, L. 2012. A Preliminary Study of Microbial Water Quality Related to Food Safety in Recirculating Aquaponic Fish and Vegetable Production Systems, Food Saf. Technol. 51: 1-11. 
[18] ICMSF. 1986. Sampling for Microbiological Analysis: Principles and Specific Applications, In: Micro-Organisms Foods 2, Second ed, International Commission on Microbiological Specifications for Foods. Blackwell Scientific Publications. pp. 1-131.

[19] Lan, N. T. P. Dalsgaard, A. Cam, P. D. Mara, D. 2007. Microbiological quality of fish grown in wastewater-fed and non-wastewater-fed fishponds in Hanoi, Vietnam: influence of hygiene practices in local retail markets, J. Water Health. 5: 209-218.

[20] Silva, F. J. A. Mara, D. D. Pearson, H. W. Mota, S. E. 1997. Informal fish culture in the Maracanaú waste stabilisation ponds in Fortaleza, Brazil, Water Sci. Technol. 42: 393-398.

[21] Dang, S. T. T. Dalsgaard, A. 2012. Escherichia coli Contamination of Fish Raised in Integrated Pig-Fish Aquaculture Systems in Vietnam, J. Food Prot. 75: 13171319.

[22] Austin, B. 2006. The Bacterial Microflora of Fish, Revised, Sci. World J. 6: 931-945.

[23] El-Shafai, S. A. Gijzen, H. J. Nasr, F. A. El-Gohary, F. A. 2004. Microbial quality of tilapia reared in fecal-contaminated ponds, Environ. Res. 95: 231-238.

[24] Mkali, A. H. Ijumba, J. Njau, K.N. 2014. Effects of Wastewater Characteristics on Fish Quality from Integrated Wastewater Treatment System and Fish Farming in Urban Areas, Tanzania, Agric. For. Fish. 3: 292-298.

[25] Ringø, E. Birkbeck, T. H. 1999. Intestinal microflora of fish larvae and fry, Aquac. Res. 30: 73-93.

[26] Mandal, S. C. Hasan, M. Rahman, M.S. Manik, M.H. Mahmud, Z. H. Islam, M. D. S. 2009. Coliform bacteria in Nile tilapia, Oreochromis niloticus of shrimp-gher, pond and fish market, World J. Fish Mar. Sci. 1: 160-166.
[27] Al-Harbi, A. H. 2003. Faecal coliforms in pond water, sediments and hybrid tilapia Oreochromis niloticus $\mathrm{x}$ Oreochromis aureus in Saudi Arabia, Aquac. Res. 34: 517524.

[28] Hussong, D. Damaré, J.M. Limpert, R. J. Sladen, W.J. Weiner, R. M. Colwell, R. R. 1979. Microbial impact of Canada geese (Branta canadensis) and whistling swans (Cygnus columbianus columbianus) on aquatic ecosystems., Appl. Environ. Microbiol. 37: 14-20.

[29] Surendraj, A. Farvin, K. H. S. Yathavamoorthi, R. Thampuran, N. 2009. Enteric Bacteria Associated with Farmed Freshwater Fish and its Culture Environment in Kerala, India, Res. J. Microbiol. 4: 334-344.

[30] Olugbojo, J. A. Ayoola, S. O. 2015. Comparative studies of bacterial load in fish species of commercial importance at the Aquaculture unit and lagoon front of the University of Lagos., Int. J. Fish. Aquac. 7: $37-43$.

[31] Al-Harbi, A. H. Uddin, N. 2005. Bacterial diversity of tilapia (Oreochromis niloticus) cultured in brackish water in Saudi Arabia, Aquaculture. 250 566-572.

[32] Shinkafi, S. A. Ukwaja, V. C. 2010. Bacteria Associated with Fresh Tilapia Fish ( Oreochromis niloticus ) Sold at Sokoto Central Market in Sokoto, Nigeria., Niger. J. Basic Appl. Sci. 18: 217-221.

[33] Turcios, A. E. Papenbrock, J. 2014. Sustainable treatment of aquaculture effluents-What can we learn from the past for the future?, Sustain. 6: 836-856. 